are human; and doctors, when they live near together, have been known to disagrec. But, putting this on one side, there remains the fact that the public vaccinator receives, vaccinates, and takes lymph from numerous children whom he has never seen before, and of whom he knows nothing, except that they have well-formed vesicles. These children, if their parents obey the law, will often be within the age at which the symptoms of inherited syphilis first skow themselves; and the public vaccinator will have no suspicion of their latent malady, and no power to prevent its diffusion. I believe that the postponement of vaccination to the age of nine or twelve months would alone be a great benefit; and I do not hesitate to take lymph from a strange child if it be the first, if the mother has had no previous abortions, and if the child itself is apparently healthy at the age of nine months.

I am quite aware that there is now a sort of common consent among medical writers to gloss over the evils that may be attendant upon vaccination, for the sake of its great and manifest benefits. In this course I cannot concur; because I think that the evils should be fairly recognised, and that they should be neutralised by proper and scientific precautions. It seems to me, however, that the positions alike of the public and of practitioners have been changed for the worse by that aggregate of useless, meddlesome, and mischievous legislation $\mathrm{known}$ as the Vaccination Acts. The practitioner loses most of his small vaccination fees, and most of the trustworthy sources of lymph by which to earn larger ones. The patient loses that guarantee for the quality of the lymph which the knowledge of the family doctor formerly supplied, and will be driven more and more to the public vaccinator. That vaccination will be increased, or small-pox diminished, I for one utterly disbelieve.

We live in wonderful times. A wrangle about office over the carcase of the Irish Church fills our newspapers, crowds our meetings, forms the common talk of our population. But a Government that does not isolate contagious diseases unless they attack eattle, and that permits every prostitute to disseminate syphilis at her own sweet will, is able to introduce a Vaccination Bill affecting every child in the kingdom, and to pass it into law almost without notice from the press or the public, and without a clear conception on the part of any single person of the results likely to follow from its adoption. I am, Sir, your most obedient servant,

Stroud, May 20th, 1868 .

Robert B. Carter.

\section{THE CHANCELLORSHIP OF EDINBURGH UNIVERSITY.}

\section{To the Editor of THa LANCEx.}

SIR, - I trust you will, with your usual fairness, allow me space in your next impression for the following reply to your correspondent of last week who signs himself "A Member of the University Council," and writes about the Chancellorship of the University of Edinburgh.

1. He says as an cbjection to the Lord Justice.General, that "He is a Tory of the 'Tories, and that under his rule the Tory element in the Senatus Academicus will crop out and be developed."

My answer is that this is not a political contest, and ought not to be made so, although the Gladstonian party are trying with all their might to do so. The Lord Justice-General, doubtless, during his political career sincerely and steadily belonged to the Tory party, to which, by the way, Mr. Gladstone originally belonged also, but which I need not say he deserted long ago. The Lord Justice-General, since be ascended the bench, has, as was his duty, bid adieu to all active part in politics, and is quite incapable of using any position in which he may be placed for any political purpose whatsoever. His supporters are drawn from all sides of politics-not only from the Tory, but also from the Liberal side. Not only does $\mathrm{Mr}$. Carlyle support him, but he is supported by such consistent Liberals as Professor Maclagan (who is chairman of his com. mittee), Professor Syme, Professor Turner, Professor Kelland, Professor Struthers (of Aberdeen), and many others: therefore there is no truth in objection No. 1 .

2. The second objection is that, as Chairman of the University Commission, he did his utmost to perpetuate the monopoly of teaching in the University, which the civil authorities, in whom the management had previously been rested, had to a considerable extent reduced.

My answer is that he found that a certain extent of extramural teaching (I believe about one-third of the whole curri- culum) was allowed to be taken for the degree of the University. This he left as he found it; he did not curtail it. He did not extend it, indeed, but this was because he believed that if it were extended the interests of the University would suffer. Therefore there is no weight to be attached to objec. tion No. 2.

3. The third objection is that, in the same capacity of Chairman of the University Commission, he deprived St. Andrews of the power of conferring degrees after due examination, thereby taking away from Scotland the only means by which a man, to whatever eminence he had raised himself in his profession, could obtain a medical degree withont residence in a university.

My answer is that it is not true that he deprived St. Andrews of the power altogether of giving degrees without the condition of residence, but left it the power of making ten such gra. duates every year. Had he left the unlimited power of making as many graduates without residence as it chose to a university which has no complete medical school and no hospital, he would have done a grievous injustice to the other Scottish universities, and among them to the Edinburgh University; and would not only not have promoted but actually discouraged high University education for medical degrees in Scotland. Therefore objection No. 3 is as futile as the two preceding ones.

4. It is said that he gave Scottish universities the power of making Masters of Surgery, which was opposed ineffectually before the Privy Council by the College of Surgeons of London and Edinburgh, and the College of Physicians of Edinburgh.

Now, even if we admit, with some, that the Mastership of Surgery was not necessary, at all events we must admit this, that in instituting it the Lord Justice-General did so in the interests of the universities and of their graduates. Why then should medical graduates be called upon to vote against the Lord Justice-General by reason of objection No. 4?

5 . The fifth objection urged against the Lord Justice-General is that he disfranchised in his University Act a large number of the medical graduates.

It is incorrect to say that he disfranchised any medical graduates; for before the University Act was passed there was no Council and no franchise. It is true that all medical graduates were not originally by the University Act put upon the roll of the University Council, because in its original constitu. tion a certain amount of residence was considered essential But no one proposed in Parliament at the time the Bill was under discussion, certainly not Mr. Gladstone, that all graduates should be enrolled. I rejoice greatly that now it is considered right that all graduates, after examination, should have the franchise. This I myself have always maintained, and $I$ can state that it is mainly to the exertions of some of the chief supporters of the Lord Justice-General that it is owing that in the Scotch Reform Bill of 1868 these claims for enrolment are acknowledged. Why the medical graduates should consider that the Lord Justive-General should have less claim to their votes on this account than Mr. Gladstone, I am at a loss to imagine.

It is said, too, in regard to the Lord Justice-General that he should not be promoted to the office of Chancellor of the University because he is a judge. But $I$ would ask, are all judges, merely because they are judges, to be excluded from such highly honourable offices as the chancellorship of universities-offices essentially non-political, whatever the Gladstone party may say? That would be hard indeed. The chancellorship of a university is of all offices, in my opinion, that for which a judge is most peculiarly fitted, because its duties, especially in judging as to proposed changes in university arrangements, will be best performed by one accustomed to exercise judicial functions. If it was right to elect Lord Cairns, who at the time of his appointment was Lord Justice of Appeal, and is now Lord Chancellor, to the Chancellorship of the Dublin University, - if it was right in Lord Cairns to accept of that office which happily he still adorns, why is it to be said that the Lord Justice-General of Scotland, a gentleman who, like Lord Cairns, has raised himself by his talents apart from all adventitious aid to his present exalted position, is disqualified? I am confident the electors will not discard so eligible a candidate as the Lord Justice-General on such base. less grounds.

One would think from the ungenerous language used by some, only a few I am glad to say, of Mr. Gladstone's supporters ayainst the Lord Justice-General, that he was a mere local mediocrity - not fit to be mentioned on the same day with Mr. Gladstone. They say Mr. Gladstone is eloquent. So is the LordJustice-General-a speaker who, in elegance of expression, 
terseness, logical precision, and power of convincing those who hear him, is fully qualified to cope even with Mr. Gladstone. They say that Mr. Gladstone is a scholar, and thoroughly rersed in all educational questions. So is the Lord JusticeGeneral-the man who by the University Act gare new life to the Scottish Universities-who, as the indefatigable chairman of the Cniversity Commission during, I believe, four years, necessarily became intimately acquainted as well with the defects as with the excellences of the Scottish University system, and has done so much to improve it. It is true that from circumstances the Lord Justice-General had a very short parliamentary career, and therefore lost the opportunity of making for himself a great parliamentary name; but all who know him (including many generous political opponents) know that he had every requisite for attaining a very high parliamentary position had he continued longer in the House of Commons.

As it is, he at an unusually early age was taken suddenly from Parliament to fill the secoud highest place on the Scottish bench; and now, as the highest judge in Scotland, he has compassed the highest possible position attainable by a Scotch lawyer. His has been a most meritorious career; for, starting in life as the son of a leading clergyman of the Church of Scotland, with slender fortune and no interest, he has achieved for himself, by the force of his brilliant talents and indomitable industry, fame, fortune, and posilion. No man is more universally known and respected throughout broad Scotland. Why, then, in electing to an honourable and distinguished office, such as the Chancellorship of our University-an office to which he has the very strongest and most peculiar claimspass by so distinguished a Scotchman as the Right Honourable John Inglis, Lord Justice-General? His election will do honour to the electors, and essentially benefit the University by securing for it the services of one who, residing on the spot, and always au courant of what is passing in the University, will perform the duties of the office with dignity, impartiality, and efficiency.

Edinburgh, June 9th, 1863. obedient servant, ANDREW WOOD, M.D.

\section{To the Editor of The LAFCET.}

SrR,--As an Englishman, and a graduate of the University of Edinburgh of thirty years' standing, I hope you will permit me to say a few words on the Chancellorship of the said University. I am glad to see THE LANCET, the old representative of the medical interests of Britain, defending the right of Mr. Gladistone, and exposing the wrong of Justice Inglis, as applicants for the vacancy created by the death of Lord Brougham. The appointment of a good man concerns the medical profession; it also concerns the University to which so many thousand graduates are bound by past and present associations; and it concerns more deeply the honours of place, position, and rank to which great men, and great men only, should aspire.

Now who are the men in the field? The one is a Scotch Judge, known only as such, and assuredly not known beyond his own jurisdiction and the environs of Edinburgh, urheard of in literature and science-a man of nesative qualities, excepting when he advocated the interests of a Tory Government of the old stamp, and then he did his best to keep Edinburgh graduates off the General Council of the University. This is worthy of remembrance by those who are doubtful how to vote and may happen to be swayed by a political bias in favour of a Conservative candidate.

Mr. Gladstone, on the other hand, was a double first at $O x$ ford in 1831, and has been mixed up with University education and University reforms all his life; he is acknowledged to be a most eminent scholar, an able legislator, an historian, a man of letters, and altogether a man of this time. His farne is not confined to London or Oxford, nor Great Britain and her dependencies, but has extended far and wide over Europe, far beyond the precincts of the English language.

There is no comparison whatever between the men. It is little better than a petty provincialism that calls the Lord Justice-General from a court that he should be careful not to stray from ; it would be more than academical and more than national to confer the chancellorship of an ancient unirersity upon so eminent and scholarly a man as Mr. Gladstone.

What will the sister universities of Great Britain and Ireland say to the appointment of an unknown Scotch Judge to the vacant post? What will the French Academy of Sciences say if they should come to read in October next that the foremost man of the age has been thrown aside by the Cniversity of
Edinburgh for "one Mronsieur Inglis!" We should be a laugh. ing-stock to Europe.

Well, Sir, you have a good cause and a good man to fight for, and I hope you will be backed by every man who values the reputation of his Alma Mater.

I am, Sir, your obedient servant,

June 9th, 1568. AN EDinbURgh Graduate is ENGLAND.

\section{THE ROYAL COLLEGE OF SURGEONS.}

\section{ABSTRACT OF MR. LE GROS CLARK'S LECTURES ON SURGICAL DIAGNOSIS.}

\section{LECTURE II}

Mr. Clari's second lecture was mainly devoted to a consideration of the value and significance of the various clements on which a surgical diagnosis is based. Before doing this, however, he explained the meaning which he attached to the words "symptom" and "sign," a meaning rather conven. tional than etymological. A "symptom" was rather medical than surgical, and implied the idea of something the presence of which indicates an abnormal condition not otherwise in itself manifest. A "sign" was rather a palpable token whereby we may recognise some material change in the body. It would be appropriate to speak of a symptom of cancer of the stomach, and a sign of cancer of the breast.

History was an important element in diagnosis, and included the previous condition of the patient, as well as the causes of his injury or disease. It was often very difficult to obtain a correct history, and needed both sagacity and patience. Leading questions were sometimes absolutely necessary, sometimes fatal, to the success of the inquiry. Of the different elements in a history, previous habits were particularly important in large towns, where over-stimulation and insufficient exercise interfered so much with the repair of injuries, and rendered necessary continued stimulation, often of a special character. The lecturer referred to a case in which the disuse of tobacco had apparently interfered with the union of a fracture. Preexisting disease and previous deformity were often most important elements in the history. The exciting causes of sur. gical disease were many, but most important were the two classes of extremes of temperature and mechanical violence.

But the existing condition of a patient must always furnish the chief sources of information. Some signs were certain; others doubtful ; and negative evidence had often a most important bearing. A tranquil pulse might be the only distinction between cerebral excitement and inflammation. Great obscurity was often occasioned by urgent symptoms masking those which were less so, but of equal diagnostic value; and ancther important source arose from the sympathetic functional derangement of organs. Disturbance of the assimilative functions was present in most forms of constitutional irritation from lccal lesions. The tongue presented indications the value of which was very great. That little member rarely deceived the intelligent inquirer, even in its silent response to his queries.

The occurrence of derangement of the intellect was common, but of very variable value in diagnosis. Temporary delirium after operation often has no significance. In other conditions, as after a head injury, it might be a most alarming symptom. Nervous delirium and delirium tremens were closely allied, and indeed thought by some surgeons to be identical,-erroneously, in Mr. Clark's opinion, since the tremor so invariable in the latter was often absent in the former, in which when present it was rather agitation than tremor. There was a close analogy between the low muttering delirium of many exhausting diseases, as gangrene, and that of typhus and typhoid. Both, he thought, depended on the presence in the blood of the uneliminated products of organic combustion.

Expression in attitude and feature was a great assistance to diagnosis. Attitude frequently expressed not only the existence, but also the character, of pain. Freedom from suffering was indicated by an easy attitude, detectable even in the recumbent posture. All persons were naturally physiognomists, and the ability to read expression was sharpened by the world, and more truly by familiarity with suffering in the sick chamber. The tint of the skin was often of considerable sig. nificance, lut more valuable perhaps to the physician than to the surgeon. Power of voluntary motion was another ele- 